\title{
The status of the White-headed Duck Oxyura leucocephala
}

\author{
ANDY J. GREEN and SIMON ANSTEY
}

\section{Summary}

The former and current status of the White-headed Duck Oxyura leucocephala is reviewed on the basis of recent census data and a literature search. The current world wintering population is estimated at 19,000 birds, with the likelihood that additional birds occur in unsurveyed wetlands in Asia. The population wintering in Pakistan appears to be declining, but there is no good evidence of current decline elsewhere in the range. The population resident in Spain is increasing. The greatest threat to the species is considered to be the spread of the introduced North American Ruddy Duck O. jamaicensis from the U.K. to the continent. Hybrids between the two species are fertile and have already been seen in Spain.

\section{Introduction}

The White-headed Duck Oxyura leucocephala is a globally threatened species currently classified as Vulnerable (World Conservation Monitoring Centre 1990) It is the only stifftail (Oxyurini) indigenous to the Palearctic, with a patchy and shrinking range across the Mediterranean region and West and Central Asia (Collar and Andrew 1988). It is largely dependent on shallow, productive, brackish to saline wetlands, particularly "endorreic" wetlands having a closed-basin hydrology and found in arid to semi-arid areas of gentle relief (Cramp and Simmons 1977, Anstey 1989). Many of these wetlands are temporary or semipermanent, leading to fluctuations in distribution and population size in response to climatic changes and annual fluctuations in rainfall. In 1988-1989, a detailed investigation was undertaken by the International Waterfowl and Wetlands Research Bureau (IWRB) and The Wildfowl and Wetlands Trust into the former and current status of the species (Anstey 1989). This paper presents an update on this information along with a summary of the previous findings.

\section{Materials and methods}

Data on the White-headed Duck were collected by an analysis of IWRB International Waterfowl Census databases (midwinter counts only, see Table 1; van der Ven 1987, 1988, Scott and Rose 1989, Perennou et al. 1990, Perennou and Mundkur 1991), literature reviews, and correspondence with people in range countries. Some 2,500 records from throughout the year have been computerized on a database. This database was used to produce total counts for recent years on a national basis and to consider population trends by analysing 
Table 1. Details of IWRB International Waterfowl Census data on White-headed Duck.

\begin{tabular}{|c|c|c|c|c|c|}
\hline Country & FY & TS & PT & PC & PS \\
\hline Spain & 1968 & 23 & $428(' 89)$ & $131(" 89)$ & La Coronela \\
\hline Algeria & 1972 & 5 & $101(' 88)$ & $98(' 88)$ & Lac Oubeira \\
\hline Tunisia & 1967 & 23 & 1,312 ('69) & 1,300 ('69) & Lac de Tunis \\
\hline Greece & $197^{\circ}$ & 2 & 423 ('9o) & 423 ('9o) & Lake Vistonis \\
\hline Bulgaria & 1970 & 7 & $40\left({ }^{\prime} 83^{\prime \prime} 88\right)$ & $38(' 88)$ & Vaya Complex \\
\hline Romania & 1969 & 3 & 37 ('69) & $30(' 71)$ & Lake Techirghiol \\
\hline Turkey & 1967 & 16 & $9,204\left({ }^{\prime} 88\right)$ & $9,200(' 88)$ & Burdur Gölü \\
\hline Cyprus & 1967 & 2 & $6\left({ }^{\prime} 85\right)$ & $6\left({ }^{\prime} 85\right)$ & Larnaca Lake \\
\hline Israel & 1967 & 7 & $303(' 88)$ & $302(' 88)$ & Jordan Valley \\
\hline Azerbaijan & 1991 & 2 & $3,620(91)$ & 3,100 ('91) & Aggol Lake \\
\hline Turkmenia & 1968 & 9 & $850(74)$ & $600(74)$ & Kelifskiye Lakes \\
\hline Iran & 1967 & 9 & $628(' 88)$ & 455 ('88) & Lake Parishan \\
\hline Pakistan & 1967 & 8 & $1,039(' 68)$ & 1,005 ('68) & Khabbaki Lake \\
\hline
\end{tabular}

FY, first year when any White-headed Duck sites were covered in the IWRB midwinter census; TS, total number of sites where White-headed Duck has occurred at least once; PT, peak total count for any one year (year in brackets); PC, peak count at any one site (year in brackets); PS, site where peak count was made.

changes in numbers of birds at sites counted consistently in recent winters. The database was also used to identify wetlands of particular importance to the species. Monitoring of the White-headed Duck population continues, and the first author requests further records for entry onto the database.

\section{Summary of present distribution}

The past and present distribution of the White-headed Duck is shown in Figure 1. Counts of the species have been received from about 130 wetlands since 1980 . Figure 2 shows 32 wetlands on which flocks of 100 or more birds have been recorded since 1980. Nine wetlands where flocks of 500 or more birds have been recorded since 1980 are individually labelled. The present distribution of the White-headed Duck is fragmented, with a small resident population in the western Mediterranean (Spain, Tunisia, Algeria) and a larger, mainly migratory population in the eastern Mediterranean and Asia. The bulk of this latter population breeds in Kazakhstan and the Russian Federation within the former Soviet Union and winters in Turkey.

\section{Past and present status in the western Mediterranean}

\section{Spain}

Spain has a resident population and Andalucia is thought to be the only area in Spain where the species has been well established, at least this century. Two hundred pairs were reported to breed in the Marismas del Guadalquivir in the 1950s (Amat and Sánchez 1982). The population declined to 22 individuals in the 1977 census, with these birds resident in lagoons of southern Cordoba province (Torres et al. 1986). Since then, an extensive conservation programme by the Andalucian authorities, along with a series of wet years, has allowed the popula- 


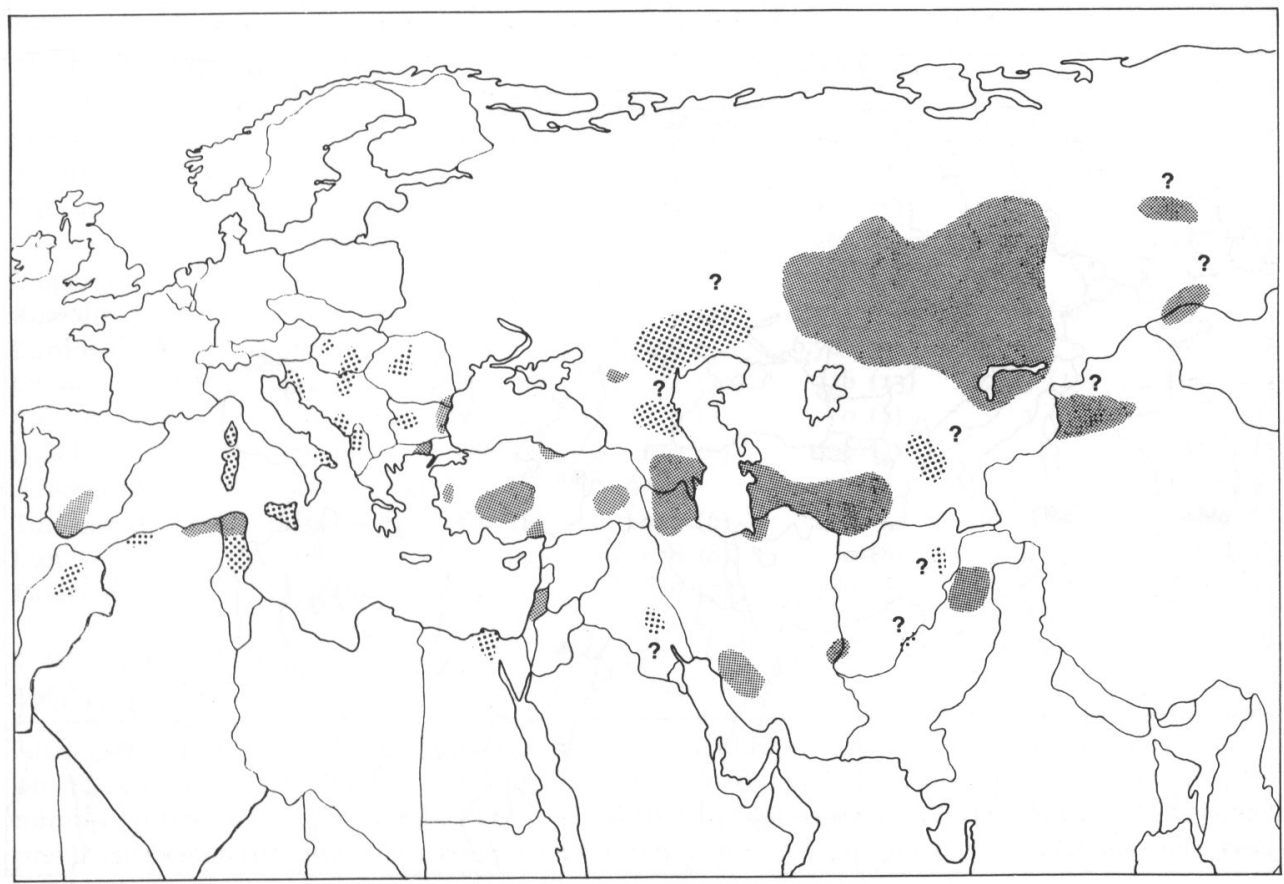

Figure 1. Past and present distribution of the White-headed Duck. Light shading shows past distribution, dark shading shows present distribution and ? indicates areas where present status is unclear.

tion to recover, with breeding occurring in many lagoons in Cádiz, Seville and Córdoba provinces and a peak census count of 580 on 30 October 1991 (Agencia de Medio Ambiente [AMA] in litt. 1991). This follows a particularly good breeding year in 1990 after heavy rains, with birds breeding at several new sites (e.g. Fuente de Piedra, Málaga). Breeding success was high in the Lagunas de Cádiz, with 124 chicks hatching and 23 fledging (J. Hidalgo in litt. 1991). As numbers increase, the species is now regularly recorded in other regions, particularly Madrid, Castilla-La Mancha and Valencia, having recently bred in the last two (García et al. 1991). Notable recent counts include 358 at Laguna de Medina in December 1988 (Sharrock 1990), 131 at La Coronela and 107 at Salada de Zorilla in January 1989 (AMA in litt. 1989), 151 at Albufera de Adra in January 1990 (AMA in litt. 1991) and 97 at Dulce, Málaga, in March 1991 (S. Pickering verbally 1991).

\section{Algeria}

Algeria has a resident population and the El Kala wetland complex (Lac Tonga, Lac des Oiseaux, Lac Oubeira) in the north-east is thought to have been the main area for the species in the last century. However, it probably also bred in Lac Fetzara (Annaba region) and Lac Holloula (Alger region) before these sites were drained in the 1930s (Heim de Balzac and Mayaud 1962; van Dijk and Ledant 1983). The White-headed Duck is currently breeding in Lac Tonga, Lac des 


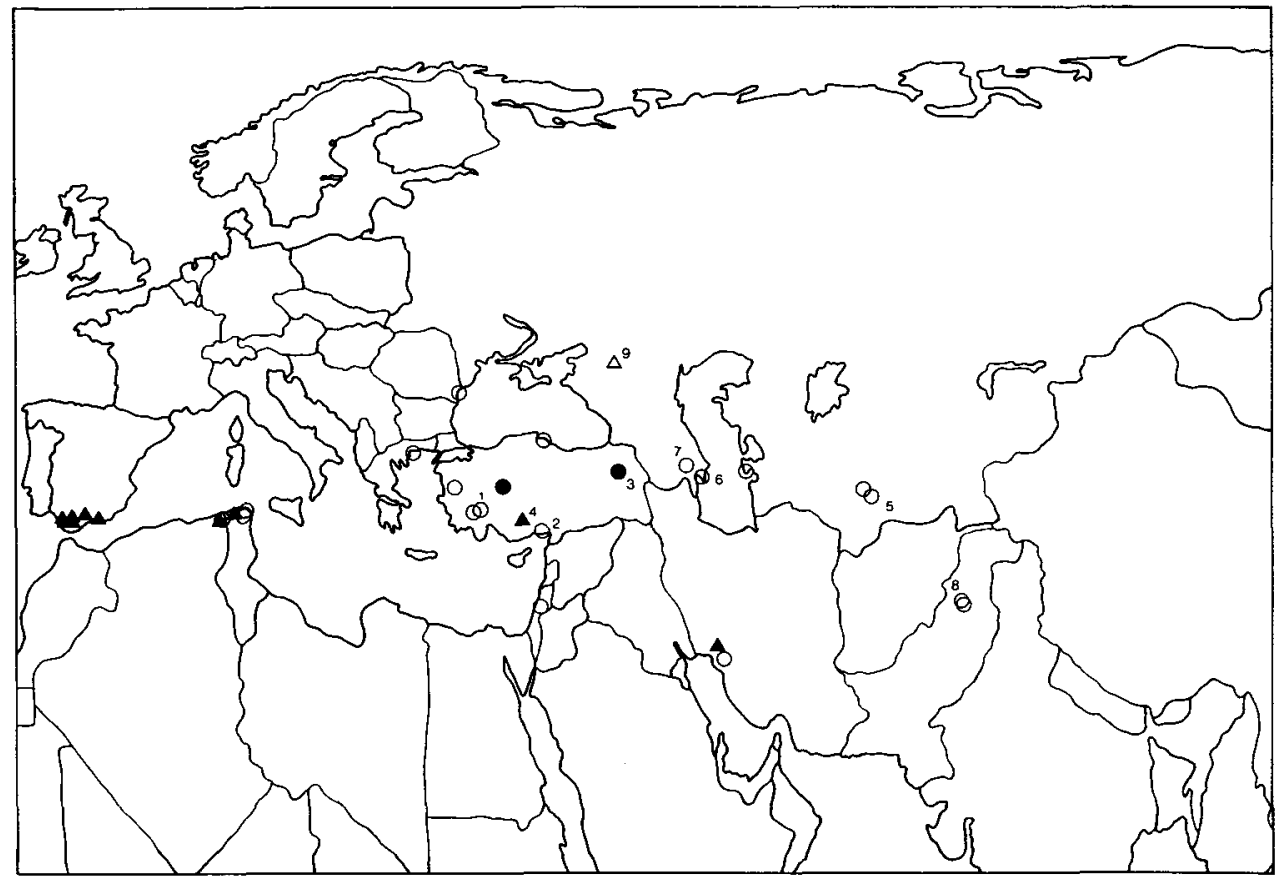

Figure 2. Thirty-two wetlands where at least one count of 100 or more White-headed Duck has been made since 1980 . Hollow circles are wintering sites, solid circles breeding sites; solid triangles are sites where the species is resident and hollow triangles passage sites. Nine wetlands where at least one count of 500 or more has been made are as follows: (1) Burdur Gölü, Turkey; (2) Akyatan Gölü, Turkey; (3) Arin/Sodali Gölü, Turkey; (4) Eregli Marshes, Turkey; (5) Lake Sultandag, Turkmenia; (6) Kirov Bay, Azerbaijan; (7) Lake Aggol, Azerbaijan; (8) Ucchali Lake, Pakistan; (9) Lake Manych/ManychTudilo, Russian Federation.

Oiseaux and Lac de Ben Azzouz, and probably also in Marais de la Mekhad. Thirty-six nests were located in 1991 (A. Boumezbeur in litt. 1991). Non-breeders and wintering birds occur on Lac des Oiseaux and Lac Oubeira (Chalabi 1990). There is no evidence of a population decline, and the highest count ever recorded was 220 on Lac Oubeira on I January 1984 (M. Smart in litt. 1989). Notable recent counts are 98 at Lac Tonga in June 1989, 125 at Lac des Oiseaux in March 1989 and 155 in March 1990 (Chalabi 1990).

\section{Tunisia}

The White-headed Duck winters regularly in northern Tunisia, but breeding has only occasionally been recorded, suggesting exchange of birds with Algeria and possibly further afield. The first breeding record, near Gabes in 1957 (Castan 1958), was during an unusually wet year. Winter numbers have declined after over 500 birds were recorded in IWRB censuses in each of 1968, 1969, 1971 and 1973 (Tables 1, 2) and a flock of 1,550 was recorded at Lac de Tunis in February 1969 (M. Smart in litt. 1989). Following major floods in 1969, the winter distribu- 
Table 2. Total mid-winter counts of White-headed Duck in recent years, by country.

\begin{tabular}{lcccccr}
\hline Country & 1986 & 1987 & 1988 & 1989 & 1990 & 1991 \\
\hline Spain & $215(14)$ & $108(16)$ & $157(17)$ & $428(23)$ & - & - \\
Algeria & $10(4)$ & $78(4)$ & $104(4)$ & $90(4)$ & $13(3)$ & - \\
Tunisia & $19(13)$ & $67(15)$ & $175(6)$ & $182(11)$ & $28(19)$ & - \\
Greece & $0(1)$ & $85(2)$ & $405(2)$ & $266(2)$ & $423(2)$ & $170(2)$ \\
Bulgaria & $1(2)$ & $2(5)$ & $40(6)$ & $28(5)$ & - & - \\
Romania & - & - & $6(2)$ & $11(3)$ & $18(2)$ & - \\
Burdur Gölü & 4,450 & 6,400 & 9,200 & 6,700 & 6,483 & 10,927 \\
Other Turkey & $442(12)$ & $230(12)$ & $4(11)$ & $326(13)$ & $1,043(13)$ & - \\
Cyprus & $0(1)$ & $0(2)$ & $0(2)$ & $0(2)$ & $1(2)$ & - \\
Israel & $70(6)$ & $186(1)$ & $620(6)$ & $396(4)$ & - & $410(1)$ \\
Azerbaijan & - & - & - & - & 0 & $3,620(2)$ \\
Turkmenia & $619(7)$ & $102(8)$ & $358(6)$ & $0(4)$ & $0(4)$ & $223(7)$ \\
Iran & $38(4)$ & $0(2)$ & $628(8)$ & $0(8)$ & $0(8)$ & $19(8)$ \\
Pakistan & $325(6)$ & $733(6)$ & $286(7)$ & $187(6)$ & $76(7)$ & $42(7)$ \\
& & & & & & \\
Total count & 6,189 & 7,991 & 11,983 & 8,357 & 8,085 & 15,411
\end{tabular}

All data from IWRB's International Waterfowl Census, with the exception of data for one site in Israel, provided by D. Allon (in litt. 1991) and 1991 data from Burdur Gölü provided by DHKD, Turkey. The number in brackets is the number of sites counted in that year where White-headed Duck has previously been recorded in at least one census. Dashes indicate years in which no data were received.

tion expanded to southern Tunisia as more wetlands became available, but from the late 1970 s the range has been restricted to the north-east of northern Tunisia (M. Smart in litt. 1989). Breeding was confirmed at three sites in 1990, a wet year: Barrage El Houareb, Barrage Sidi Abdelmoneim and Menzel Bourguiba lagoon (F. Maamouri in litt. 1991) Notable recent counts are 107 at Gdir el Ghoul, December 1988, 95 at Lac Ichkeul in January 1989 (T. Rigaux in litt. 1989) and 136 at Mornaguia in October 1989 (F. Maamouri in litt. 1991).

\section{Other countries}

The White-headed Duck bred in northern Morocco at the turn of the century and was not regarded as rare (Heim de Balsac and Mayaud 1962, M. Thévenot in litt. 1989). Only vagrant birds have been recorded since the 1950s (Louette 1973). In France, small numbers were recorded breeding on Lake Buguglia and other Corsican wetlands until the 1960s (P. Dubois in litt. 1989). In Italy, breeding and wintering was formerly recorded in Puglia, Sardinia and probably Sicily (E. Grandi and C. G. Violani in litt. 1989). The last breeding record was from Oristano, Sardinia, in 1976 (Schenk 1976) and only vagrant birds are now recorded.

\section{Past and present status in the eastern Mediterranean}

\section{Turkey}

Turkey has the largest wintering population of the White-headed Duck and a smaller breeding population. The southern coastlands and central plateau hold 
major breeding and wintering sites, while eastern Turkey holds breeding and passage sites. Wintering is also recorded in the Black Sea coastlands and western Anatolia (see Beaman 1986 for regions). The wintering population is at least 11,000 birds, while Green and Moorhouse (1989) estimated the number of resident birds at 750 with 150 to 200 breeding pairs. The number of Turkish breeding pairs is likely to be higher than this figure, as G. Kirwan (in press) found evidence that the breeding population in 1991 was about 150 pairs on the central plateau alone.

The most important site in Turkey is Burdur Gölü, which may hold over $50 \%$ of the world population during winter (Table 2). In February 1991 there was a record count of 10,927 birds on the lake (Berrevoets and Erkman 1991), and 2,054 birds were still present when the lake was counted in early April 1991, an unusually high number for so late in the year (G. Magnin in litt. 1991). These data suggest that reduced disturbance following recent protection of the site may be having a positive effect. Alternatively, it may simply reflect a more accurate count than in previous years, as the large size of the lake, access problems and weather conditions make accurate counting difficult (L. J. Dijksen in litt. 1991) and even the record count may have been an underestimate (Berrevoets and Erkman 1991). Other remarkable recent counts include 900 at Akyatan Gölü in January 1990 (IWRB), c. 800 at Arin Gölü and c. 400 at Kulu Gölü in September 1988 and c. 750 at Arin Gölü in August 1990 (I. A. Green and C. N. Moorhouse in litt. 1991), 508 at Eregli Marshes in March 1990 (G. Magnin in litt. 1991) and 354 at Hotamis Marshes in April 1991 (Kirwan in press).

There is no historical evidence of a decline in the Turkish population. The IWRB International Waterfowl Census counts have been particularly thorough in Turkey and for eight years since 1971 (1971-1973 and 1986-1990 inclusive), 11 sites have been counted each year. There is no evidence of a decline in numbers at Burdur Gölü or the other sites over this period (Spearman Rank Correlations: for Burdur Gölü vs. year $r_{\mathrm{s}}=+0.48 \mathrm{NS}$; for other sites combined vs. year $r_{\mathrm{s}}=$ +0.19 NS). There is however a significant negative correlation between the numbers at Burdur Gölü and the numbers at the other sites combined $\left(r_{\mathrm{s}}=\right.$ $-0.643, n=8, P=0.05$ ). This suggests that in years when the Burdur Gölü count is high, the Turkish population is highly concentrated at this lake, while in years when the Burdur Gölü count is low, more birds have dispersed to other lakes. However, this correlation may be a chance effect as the variation in counts on Burdur Gölü between years may be more a reflection of changes in counting conditions than in real changes in numbers (L. J. Dijksen in litt. 1991).

\section{Israel}

In the last century the White-headed Duck was considered a common resident on Lakes Tiberias and Hula, but breeding has not been recorded for at least 50 years ( $\mathrm{Paz} 1987$ ). A wintering population has remained, and the known wintering population increased markedly following the creation of a reservoir in 1984, Tishlovet Hakishon. The numbers have increased steadily each winter, from a peak count of 70 in 1986 to 410 in 1991 (D. Allon in litt. 1991; Table 3). It is unknown whether these increasing numbers reflect a genuine increase in 
Table 3. Midwinter counts of White-headed Duck for constantly counted sites (those counted in each year from 1986 to 1991 with some birds present in at least one year).

\begin{tabular}{lrrrrrrrr}
\hline Country & NS & 1986 & 1987 & 1988 & 1989 & 1990 & 1991 & Trend \\
\hline Spain & 10 & 215 & 55 & 81 & 285 & - & - & +0.4 \\
Algeria & 2 & 10 & 78 & 101 & 90 & 13 & - & +0.3 \\
Tunisia & 4 & 0 & 49 & 175 & 161 & 7 & - & +0.3 \\
Greece & 1 & - & 85 & 405 & 266 & 423 & 170 & +0.3 \\
Bulgaria & 2 & 1 & 1 & 2 & 28 & - & - & +0.95 \\
Romania & 2 & - & - & 6 & 11 & 18 & - & +1.0 \\
Turkey & 9 & 4,892 & 6,630 & 9,204 & 7,026 & 7.526 & - & +0.7 \\
Israel & 1 & 70 & 186 & 317 & 396 & - & 410 & $+1.0 * *$ \\
Turkmenia & 3 & 579 & 43 & 358 & 0 & 0 & 0 & $-0.88^{*}$ \\
Iran & 3 & - & - & 628 & 0 & 0 & 19 & -0.32 \\
Pakistan & 4 & - & 733 & 286 & 187 & 76 & 42 & $-1.0 * *$ \\
\hline
\end{tabular}

NS, number of sites. Trends were analysed with Spearman Rank Correlation. All data are from IWRB's International Waterfowl Census, with the exception of data for the site in Israel (D. Allon in litt. 1991). Dashes indicate years in which the sites were not counted. ${ }^{*} p<0.05 ;{ }^{* *} p=0.01$.

population size or simply a movement of birds from other wetlands in Israel or elsewhere.

\section{Greece}

Cramp and Simmons (1977) report that the White-headed Duck may have bred in Greece in the 1950s. In recent years, a significant wintering population has developed in Porto Lago, and Lake Vistonis has become a major wintering site, with a peak count of 423 in January 1990 (G. Handrinos in litt. 1991; Table 3).

\section{Romania}

The White-headed Duck formerly bred in the lakes of Transylvania, with the last record from Săulia in 1908. Breeding was recorded in the Danube Delta, Dobrodja, in May 1986, when eight adults and three young were seen on channels between Crisan and Maliuc (R. F. A. Grimmett in litt. 1991). The last previous breeding record in the Danube Delta was from Lake Agigea in 1957 (D. Munteanu in litt. 1989). The Danube Delta has been used as a wintering site since at least the 1960 s and there is no evidence of a decline (Table 3). The delta is also an important site for autumn passage (D. Munteanu in litt. 1989) and 218 were counted on Lake Techirghiol in November 1982 (D. A. Scott in litt. 1983).

\section{Bulgaria}

From the 1890s to 1940 s the White-headed Duck was recorded wintering or on passage in the west of Bulgaria (around Sofia) and along the Black Sea coast (Botev and Peshev 1985). There are no recent records from the west but small numbers continue to winter along the Black Sea coast (Table 2). 


\section{Other countries}

The White-headed Duck was not recorded in Yugoslavia until the 1880s when wintering birds were observed in coastal Hrvatska, coastal Bosnia/Hercegovina and Vojvodina. Small numbers were recorded breeding between the 1930 s and 1965 in Vojvodina at lakes Ludas, Palic and Saskopo (J. Mikuska in litt. 1989) but only winter vagrants are now recorded. Breeding was recorded in Hungary from 1853 onwards around the northern Danube and between the Danube and the Tisza (von Schmidt 1967, Bauer and Glutz von Blotzheim 1969). The last confirmed breeding was at Lake Kondor in 1961 (Molnár 1987) although breeding may have occurred at Lake Nádas in 1971 (L. Molnár in litt. 1990). Since then only vagrants have been recorded. In Albania, breeding occurred at Lake Shkodra (Scutari) in the 1920s (F. Lamani in litt. 1989), but only vagrants have since been recorded. In Egypt, the White-headed Duck was "tolerably plentiful" in winter at Lakes Maruit and Menzaleh in the Nile wetland complex in the last century. Forty birds were shot in the area in 1925 (Meinertzhagen 1930) but there have been no recent records. Small numbers have recently been recorded wintering in Cyprus (Tables 1, 2).

\section{Past and present status in the former U.S.S.R. and Asia}

\section{Former U.S.S.R.}

The former Soviet Union holds most of the world breeding population of the White-headed Duck and a significant part of the wintering population. The current breeding population has been estimated at 10,000 birds with 900-1,200 pairs (V. Krivenko and V. V. Morozov in litt. 1989), but there have been no systematic counts and these figures are open to a wide margin of error. The differences between former and present breeding distributions are unclear, but the following summary is largely based on Dementiev and Gladkov (1952), IZASK (1978), Ivanov (1983), Borodin (1984), Bakkal et al. (1990), Stepanyan (1990) and V. Krivenko and V. V. Morozov (in litt. 1989). Breeding is concentrated in the steppes of Kazakhstan and the Russian Federation. In Kazakhstan, breeding areas include: the Aktyubinsk Steppe and lower llek river in the north-west; lower Turgai and Irgiz north of the Aral Sea; Kurgaldzhin and Tengiz lakes in the central north; Balkash Alakol Depression in the east; middle and lower Syr Darya in the south (breeding may no longer occur here). In the Russian Federation, breeding used to occur in the Sarpa lowlands between Volgograd and the Caspian and in the Volga/Ural steppes. It has also been recorded along the Upper Yenesei near Krasnoyarsk and in the Tuva and Ubsu Nura Depressions on the Mongolian border. Breeding continues on wetlands between the Tobol and Ishim rivers in west Siberia. The species has also been recorded in the northern Caucasus and along the western coast of the Caspian. On the borders between west Siberia and Kazakhstan breeding occurs to the east of the Urals around Kustanai and possibly in the Chelyabinsk Oblasts. The most important breeding area is now thought to be further east along this border, in the Kulunda and Baraba forest steppes. Breeding was formerly recorded in the Lake Sevan area of Azerbaijan, along the lower Amu Darya 
and Tedzhen/Murgab rivers in Turkmenia and on the Afghanistan border in Tadjikistan. Breeding was recently confirmed at Lake Sultandag, southern Turkmenia, where 19 breeding pairs were recorded in 1989 (A. Poslavski in litt. 1991). The species has been recorded in the Ukraine as far west as the west coast of the Sea of Azov.

Birds have wintered in southern Turkmenia along the Caspian Sea, lower Amu Darya, Tedzhen and Murgab rivers since at least the 1950s. Recently received Turkmenian midwinter counts back to 1968 (Tables 1,2$)$ record Whiteheaded Duck at nine sites and flocks of 200 or more at five of them (Figure 2; Khauzhkhan reservoir; Kelifskiye lakes; Lake Sultandag; Lake Kyzylburun; Krasnovodsk and North-Cheleken Bays). The peak count for the region was 850 in 1974, with 600 at Kelifskiye lakes. The last notable count was 223 at Krasnovodsk and North-Cheleken Bays in 1991.

In the late 1960s, the White-headed Duck was recorded wintering in southeast Kazakhstan on the middle Syr Darya (Isakov 1970). In 1991 over 3,100 birds were counted in Lake Aggol and 520 in Kirov Bay in Azerbaijan (Figure 2). This makes Lake Aggol by far the most important wintering site for White-headed Duck after Burdur Gölü, although there is no mention of the species from previous censuses at the site in the 1960s. There is however an unconfirmed record of 5,000 birds in Kirov Bay in the 1960s (M. Patrekeev in litt. 1991). Use of Aggol and neighbouring sites is perhaps dependent on the severity of the winter. Improved monitoring of this region is clearly required.

The Manych valley in the Russian Federation is a major spring and autumn migration site for the species, probably for birds wintering in Turkey (Ivanov 1983). On 27 October 1980, 1, 200 White-headed Duck were counted on a $100 \mathrm{~km}$ transect bisecting the saline Lake Manych and Lake Manych-Gudilo (Linkov 1984).

Iran

There is a resident population of White-headed Duck in southern Zagros and the Persian Gulf (Fars and Bushire provinces), a breeding population in Azerbaijan province in the north-west and a wintering population on the south-east coast of the Caspian (Mazandaron and Gorgan provinces: D. A. Scott in litt. 1989). There is also a wintering population in the wetlands of the Seistan lowlands (Seistan province) that continue across the Afghanistan border, but these wetlands flood and dry out for several years at a time and in dry years the ducks winter elsewhere (D. A. Scott in litt. 1991). The wintering population in the Caspian is higher in more extreme winters as birds move south from states of the former U.S.S.R. (D. A. Scott in litt. 1989). However, there is no evidence that the total Iranian wintering population has ever exceeded 1,00o birds (Table 1). Few birds have been recorded in the midwinter census since 1988, when 455 were counted on Lake Parishan and 173 in Hele region (Table 2); 232 were counted at Lake Parishan in October 1991 (B. Behrouzi-Rad verbally 1991).

\section{Pakistan}

Pakistan regularly holds White-headed Duck during the winter, concentrated in the Salt Range lakes of Punjab with occasional records from Sind, Baluchistan, 
North-West Frontier Province and Capital Federation Territory. Although there are records from Punjab since at least 1921, there were no reports of large numbers until censuses began in the 1960 s when a peak of 1,039 were counted in 1968 (Savage 1965, 1968; Table 1). Numbers have recently been falling steadily (Tables 2, 3), with no notable midwinter counts since January 1989, when 100 were counted at Ucchali Lake (IWRB). However, 105 were seen in November 1990 at Jahlar Lake (A. A. Chaudhry in litt. 1991), and 142 at Khabbakki Lake in December 1991 (A. J. Green pers. obs.). An unusual sighting of six during the breeding season was made at Jahlar Lake in May 1990 (D. A. Scott in litt. 1990).

\section{Other countries}

Small numbers of White-headed Duck have been recorded in winter in Saudi Arabia at Doumat Al Jandal, Tabuk and Yanbu (P. Symens verbally 1991). Small numbers have formerly been recorded wintering in Iraq in the Euphrates/Tigris wetland complex, which contains huge areas of apparently suitable habitat that have never been properly surveyed (George and Savage 1970, D. A. Scott in litt. 1991). In Afghanistan, the species was resident in Seistan wetlands near the Iran border at the turn of the century, and was still wintering there in the 1970s (D. A. Scott in litt. 1991). Birds were seen from March to August in the 1970s at Ab-e-Estada on the Pakistan border and at Kole Hashmat Khan near Kabul (Sayer and van der Zon 1981). Breeding has been recorded in China in the Junggar Basin and Tienshan Mountains in Xinjiang Uygar Autonomous Region near the Kazakhstan border. The one wintering record is from Honghu Lake, Hubei province (Cheng Tso-hsin 1987). Breeding was recorded in northern Mongolia in the 1940s in the Ubsa Nur depression (Dementiev and Gladkov 1952). In northern India, the species is regularly reported in winter at Harike Lake in Punjab (Scott 1989). Small numbers have formerly been recorded wintering in Kashmir, Delhi District and Uttar Pradesh (Ali and Ripley 1968).

\section{Current population size}

On the basis of recent winter counts (Tables 1, 2), the present world population of White-headed Duck can be conservatively estimated at 19,000 birds. The western Mediterranean population can be estimated at 1,000 (600 in Spain and 400 in North Africa) with a 1989 count of 700 . The eastern Mediterranean wintering population can be estimated at 13,000 (12,000 for Turkey and neighbouring countries; 1, ooo for the Israel area) with a 1991 count of 11,507. The south-west Asian wintering population can conservatively be estimated at 5,000 with a 1991 count of 3,904. Many potential wintering sites in south-west Asia still have an unknown fauna, particularly in Iraq, Afghanistan and the former U.S.S.R., and this population is likely to be underestimated.

\section{Threats and causes of decline}

The range of the White-headed Duck has contracted markedly this century (Figure 1). However, there are few data to assess the changes in the total population size resulting from this decline in range. The historical evidence 
suggests that many of the extinct populations were probably very small, and the disappearance of breeding populations from Morocco, Egypt, Israel, France, Italy, Yugoslavia, Hungary and Albania may have resulted in the loss of less than 1,00o birds in total. A decline in the main population breeding in the former Soviet Union is suggested by anecdotal reports of up to 50,000 birds wintering in the south-east Caspian in the 1930s (Dementiev 1952). There have been no records of over 1,000 White-headed Duck in the Caspian Sea since the 1960s. A decline has certainly occurred in the population of Red-breasted Geese Branta ruficollis wintering in the south-west Caspian from 40,000 in the 1950 s to only a few hundred since 1970, following a shift in wintering grounds to Black Sea coasts (Krivenko 1983).

There is very little evidence for a current decline in the size of the Whiteheaded Duck populations. Analysis of trends in count data for sites counted consistently in recent winters shows no evidence of a continuing decline in the western Mediterranean population (Table 3), with Spain, Tunisia and Algeria all showing a slight positive trend. Likewise, there is no evidence of a continuing decline in the eastern Mediterranean population (Table 3), with Turkey, Greece, Romania, Bulgaria and Israel all showing a positive trend. In contrast, in southwest Asia, winter counts in Turkmenia, Iran and Pakistan all show a negative trend (Tables 2, 3). In Iran and Turkmenia, however, there is no evidence that these figures reflect a genuine decline. They are likely to result from incomplete data that do not truly reflect the size of the wintering population, as Whiteheaded Ducks typically change sites from one winter to the next, and only a small proportion of these sites are counted. In addition, many sites are very large and impossible to count accurately. In Pakistan the trend probably reflects a genuine decline in the size of the wintering population, as the three most important lakes (Khabbakki, Ucchali and Jahlar) have all been severely degraded in recent years by over-grazing, fish introductions and increased hunting, and are decreasing in size following the diversion of rainwater for irrigation (Scott 1989, A. A. Chaudhry in litt. 1991).

It is difficult to establish to what extent the changes in distribution and population size observed in the White-headed Duck over the past two centuries result from natural oscillations. Some of the changes are explained by the fact that the White-headed Duck is dependent on wetlands subject to major fluctuations in water level between years. The White-headed Duck is an opportunistic species able to utilize ephemeral wetlands as and when they appear. Thus, some breeding populations in former range countries may have been only marginal populations that appeared and later disappeared as a result of these fluctuations. Variation in rainfall between years plays a major part in determining distribution, breeding success and population size in Spain (Amat and Raya 1989), Tunisia (M. Smart in litt. 1989) and elsewhere. There is some evidence that a drying in climate this century has caused a shrinkage of the main breeding range in the former U.S.S.R. as well as a shift in the range to the north and east (Krivenko 1990).

However, human influence has undoubtedly contributed to the reduction in the White-headed Duck's range and probably also to declines in population size within the current range. Drainage and degradation of wetlands of former importance for breeding and wintering has occurred across the range. This has 
included degradation of large areas of wetlands in the steppelands of the former U.S.S.R. through water management schemes and conversion for agriculture (Borodin 1984, Bakkal et al. 1990), and drainage of $60 \%$ of lagoons in Andalucia this century (AMA in litt. 1991). In some areas (e.g. Tunisia) the White-headed Duck is now making extensive use of artificial reservoirs and these may partially compensate for the loss of natural habitats if managed appropriately.

The fact that many of the wetlands used by White-headed Duck are endorreic (i.e. with a closed-basin hydrology) makes them particularly vulnerable to degradation through pollution. This is of particular concern at Burdur Gölü, where large quantities of human and industrial effluent are currently discharged into the lake (DHKD in litt. 1991). In some Spanish wetlands, breeding success of the White-headed Duck has been adversely affected by introductions of carp, eels and Louisiana crayfish Procambarus clarkii thought to affect food supply by direct competition and by causing turbidity.

Hunting of White-headed Duck still occurs across most of the range, and is a particular threat where the species occurs in small numbers. Hunting and egg collection was probably the final cause of extinction in France, Italy, Yugoslavia and Egypt. Effective protection from illegal hunting in Spain has played a vital role in the recent recovery of the Spanish population (Amat and Raya 1989) and action to control hunting is now being taken elsewhere in the range. A recent education programme by IWRB, The Wildfowl and Wetlands Trust and DHKD (Turkish Society for the Protection of Nature) led to a hunting ban at Burdur Gölü and Yarisli Gölü in Turkey from December 1990 onwards. In 1989, WWF Pakistan and the Punjab government launched a three-year project to protect the White-headed Duck at three sites, providing guards and mounting public awareness campaigns (A. A. Chaudhry in litt. 1990).

The greatest threat to the survival of the White-headed Duck is from hybridisation and competition with the North American Ruddy Duck O. jamaicensis introduced into the U.K. in the 1950 s and now spreading across the continent as it undergoes exponential population growth (Hudson 1976, Hughes 1991). The Ruddy Duck appears well able to exploit a wide range of wetland types and has already been recorded in at least 12 European countries (Hughes 1991). Since December 1989, there have been 29 sightings of groups of up to five Ruddy Duck in 10 wetlands of Seville and Cádiz occupied by White-headed Duck. Male Ruddy Ducks have been seen readily to court female White-headed Ducks and attempt copulations with them. In addition, there were at least two sightings of hybrids in Andalucia in 1991 (AMA in litt. 1991). Hybrids between the two species have been produced at the Wildfowl and Wetlands Trust U.K. where they have been shown to be fertile and able to interbreed sucessfully with each other and with White-headed Duck. While the Spanish population is under imminent threat, in the long term the Ruddy Duck could become an abundant species across the whole of the White-headed Duck's range and the gene pools of the two species could merge. 


\section{Priorities for future action}

While the White-headed Duck currently appears to be stable or increasing in numbers across much of its range, the species and its habitat is poorly protected in many areas and there remains a need for conservation action to prevent future declines. Burdur Gölü and Lake Aggol should be granted effective protection from habitat degradation and hunting. Effective habitat protection is urgently required in the Salt Range of Pakistan, where the White-headed Duck population could potentially go extinct within a few years.

More detailed monitoring of the White-headed Duck is required during the breeding season, particularly in the former Soviet Union where current distribution is very unclear. Without this information it will not be possible to ensure conservation of the main population by providing effective protection on its wintering grounds. Similarly potential wintering sites in Afghanistan and Iraq should be surveyed as soon as it becomes possible.

A flyway management plan would be a very valuable tool for maintaining the current range and abundance of White-headed Duck and allowing for possible expansion. Flyway conservation is particularly appropriate for this species owing to its frequent movements between different breeding or wintering sites within a flyway. Such a plan is called for in the draft Western Palearctic Waterfowl Agreement (Boere and van Roomen 1991), which would provide a suitable forum for its successful implementation.

However, the highest priority for action to conserve White-headed Duck must now be to prevent the Ruddy Duck from becoming fully established on the European continent by any means available.

\section{Acknowledgements}

This work has been financially supported by WWF-U.K., U.S. Fish and Wildlife Service and the Whitley Animal Protection Trust. We would like to thank all those who contributed to the production of Anstey (1989). Further assistance has been received from $D$. Allon, B. Behrouzi-Rad, A. Boumezbeur, B. Chalabi, A. A. Chaudhry, L. J. Dijksen, A. D. Fox, I. A. Green, R. F. A. Grimmett, G. Handrinos, J. Hidalgo, B. Hughes, M. Macpherson, F. Maamouri, G. Magnin. F. Monina, L. Molnár, C. N. Moorhouse, M. Moser, D. Munteanu, M. Owen, M. Patrekeev, C. Perennou, S. Pickering, R. Pintos, A. Poslavski, P. Rose, D. A. Scott, P. Symens, V. Taylor, J. Torres and M. Yarar. Special thanks go to DHKD, AMA and Punjab Wildlife Research Centre for their assistance and to D. A. Scott for his valuable comments as a referee. L. Webber and M. Bertuca prepared the figures and J. Dunning translated Russian publications.

\section{References}

Ali, A. and Ripley, S. D. (1968) Handbook of the birds of India and Pakistan. Bombay: Oxford University Press.

Amat, J. A. and Raya, C. (1989) Aves en la lista roja: la Malvasía. La Garcilla 75: 8-11.

Amat, J. A. and Sánchez, A. (1982) Biología y ecología de la Malvasía Oxyura leucocephala en Andalucía. Doñana Acta Vert. 9: 251-320. 
Anstey, S. (1989) The status and conservation of the White-headed Duck Oxyura leucocephala. Slimbridge, U.K.: International Waterfowl and Wetlands Research Bureau (Spec. Publ. 10).

Bakkal, S. N., Bardin, A. V., Darevski, I. S., Kozlov, M. A., Kryzmanovski, O. L., Neyelov, A. V., Orlov, N. L., Pavlova, Ye. A., Payevski, V. A., Potapov, R. L., Sokolov, V. Ye., Starobogatov, Ya. I., Tanasichur, V. N. and Shumakov, M. Ye. (1990) [Rare animals of our country.] Leningrad: Nauka. (In Russian).

Bauer, K. M. and Glutz von Blotzheim, U. N. (1969) Handbuch der Vögel Mitteleuropas, 2(2). Frankfurt am Main: Akademische Verlagsgesellschaft.

Beaman, M. (1986) Turkey Bird Report 1976-1981. Sandgrouse 8: 1-41.

Berrevoets, C. and Erkman, A. (1991) Count of White-headed Duck Oxyura leucocephala in Burdur Gölü, February 1991. Unpublished report.

Boere, G. C. and van Roomen, M. W. J. (1991) Draft Western Palearctic Waterfowl Agreement under the Bonn Convention. Ministry of Agriculture, Nature Management and Fisheries, the Netherlands.

Borodin, A. M., ed. (1984) [The Red Data Book of the USSR], 1. Second edition. Moscow: Promyshlennost.

Botev, B. and Peshev, T., eds. (1985) ["Red Data Book of the People's Republic of Bulgaria, 2"]. Sofia: Bulgarian Academy of Sciences. (In Bulgarian).

Castan, R. (1958) Notes de Tunisie. Alauda 25: 56-62.

Chalabi, B. (1990) Contribution à l'étude de l'importance des zones humides algériennes pour la protection de l'avifaune. Alger: Thèse de Magister, Institut National Agronomique.

Cheng Tso-hin (1987) A synopsis of the avifauna of China. Hamburg and Berlin: Paul Parey Scientific.

Collar, N. J. and Andrew, P. (1988) Birds to watch: the ICBP world checklist of threatened birds. Cambridge, U.K.: International Council for Bird Preservation (Techn. Publ. 8).

Cramp, S. and Simmons, K. E. L., eds. (1977) The birds of the western Palearctic, 1: Ostrich to ducks. Oxford: Oxford University Press.

Dementiev, G. P. (1952) [Birds of Turkmenistan.] Ashkhabad: Academy of Sciences of the Turkmen SSR. (In Russian).

Dementiev, G. P. and Gladkov, N. A., eds. (1952) Birds of the Soviet Union, 4. Moscow. (English translation, Jerusalem 1967).

van Dijk, G. and Ledant, J. P. (1983) La valeur ornithologique des zones humides de l'est Algérie. Biol. Conserv. 26: 215-226.

García, J. C. D., Ripoll, M. G. and Pedrero, J. H. (1991) Status of some threatened Anatidae species in the Communidad Valenciana, East Spain. IWRB Threatened Waterfowl Research Group Newsletter No. 1.

George, P. V. and Savage, C. D. W. (1970) Status of the species of wildfowl occurring in Iraq. Pp.177-181 in Yu. A. Isakov, ed. Proceedings of the international regional meeting on conservation of wildfowl resources, Leningrad, USSR, 25-30 September 1968. Moscow.

Green, I. A. and Moorhouse, C. N. (1989) White-headed Duck in Turkey. A study of their breeding status and distribution. Unpublished report.

Heim de Balzac, H. and Mayaud, N. (1962) Les oiseaux du nord-ouest de l'Afrique. Paris: Lechevalier.

Hudson, R. (1976) Ruddy Ducks in Britain. Brit. Birds 69: 132-143.

Hughes, B. (1991) The status of the North American Ruddy Duck Oxyura jamaicensis in Great Britain. Pp. $162-163$ in D. Stroud and D. Glue, eds. Britain's birds in 1989-1990: the conservation and monitoring review. Thetford, U.K.: British Trust for Ornithology/Nature Conservancy Council.

Institute of Zoology Academy of Science of Kazakh (IZASK) SSR (1978) ["Red data book of Kazakh SSR. Part 1: vertebrates."] Alma-ata: Kainar. (In Russian). 
Isakov, Yu. A., ed. (1970) Proceedings of the international regional meeting on conservation of wildfowl resources, Leningrad, USSR, 25-30 September 1968. Moscow.

Ivanov, G. K. (1983) [The White-headed Duck Oxyura leucocephala.] Pp. 195-196 in A. M. Kolosov, ed. Red data book of the RSFSR: animals. Moscow: Rossel 'khozizdat. (In Russian).

Kirwan, G. (in press) The breeding status and distribution of the White-headed Duck Oxyura leucocephala on the central plateau, Turkey. Sandgrouse.

Krivenko, V. G. (1983) [The Red-breasted Goose Branta ruficollis.] Pp. 177-180 in A. M. Kolosov, ed. Red data book of the RSFSR: animals. Moscow: Rossel 'khozizdat. (In Russian).

Krivenko, V. G. (1990) Effect of climate on the dynamics of waterfowl numbers and their ranges. Pp. 182-186 in G. V. T. Matthews, ed. Managing waterfowl populations. Slimbridge, U.K.: International Waterfowl and Wetlands Research Bureau (Spec. Publ. 12).

Linkov, A. B. (1984) [Oxyura leucocephala ecology in Eastern Manych.] Pp.85-86 in Present status of waterfowl resources. Proceedings of the All-Union Seminar, Moscow, 20-23 October 1984. (In Russian).

Louette, M. (1973) Ornithological observations near fresh- and brackish water in Morocco during summer 1971. Gerfaut 63: 121-132.

Meinertzhagen, R. (1930) Nicholl's birds of Egypt. London: Hugh Rees.

Molnár, L. (1987) Programme of the HOS for the reintroduction of the White-headed Duck Oxyura leucocephala to Hungary. In: Saving the birds (Hungarian Ornithological Society pamphlet).

Paz, U. (1987) The birds of Israel. Bromley: Christopher Helm.

Perennou, C. and Mundkur, T. (1991) Asian waterfowl census 1991. Slimbridge, U.K.: International Waterfowl and Wetlands Research Bureau.

Perennou, C., Rose, P. and Poole, C. (1990) Asian waterfowl census 1990. Slimbridge, U.K.: International Waterfowl and Wetlands Research Bureau.

Savage, C. D. W. (1965) White-headed Ducks in Pakistan. Wildfozol Trust Ann. Rep. 16: 121-126.

Savage, C. D. W. (1968) The wildfowl and wetlands situation Afghanistan/West Pakistan/ Iran/Iraq/the Levant. Pp.115-119 in Proceedings of a technical meeting on wetland conservation, Ankara-Bursa-Istanbul, October 1967. Morges, Switzerland: International Union for Conservation of Nature and Natural Resources.

Sayer, J. and van de Zon, A. F. W. (1981) National parks and wildlife management in Afghanistan: a contribution to conservation strategy. FAO Technical Report, FAO, Rome.

Schenk, H. (1976) Analisi della situazione faunistica in Sardegna. Uccelli e mammiferi. Pp.465-556 in S.O.S. fauna, animali in pericolo in Italia. Camerino: World Wildlife Fund-Italy.

von Schmidt, E. (1967) Die Ruderente Oxyura leucocephala im Karpatenbecken. Anz. Orn. Ges. Bayern (8)2: 123-128.

Scott, D. A. (1989) A directory of Asian wetlands. Gland, Switzerland, and Cambridge, U.K.: International Union for Conservation of Nature and Natural Resources.

Scott, D. A. and Rose, P. M. (1989) Asian waterfowl census 1989. Slimbridge, U.K.: International Waterfowl and Wetlands Research Bureau.

Sharrock, J. T. R. (1990) European news. Brit. Birds 83: 11.

Stepanyan, L. S. (1990) ["Conspectus of the ornithological fauna of the U.S.S.R."]. Moscow: Nauka. (In Russian).

Torres, J. A., Arenas, R. and Ayala, J. M. (1986) Evolución histórica de la población española de Malvasía (Oxyura leucocephala). Oxyura 3: 5-19.

van der Ven, J. (1987) Asian waterfowl 1987. Slimbridge, U.K.: International Waterfowl and Wetlands Research Bureau. 
van der Ven, J. (1988) Asian waterfowl 1988. Slimbridge, U.K.: International Waterfowl and Wetlands Research Bureau.

World Conservation Monitoring Centre (1990) IUCN red list of threatened animals. Gland, Switzerland, and Cambridge, U.K.: IUCN, The World Conservation Union.

ANDY J. GREEN

IWRB Threatened Waterfowl Research Group, The Wildfowl and Wetlands Trust, Slimbridge, Glos., GL2 7BT, U.K.

SIMON ANSTEY

Yew Tree House, Corscombe, Dorset, DT2 oNX, U.K. 